University of Montana

ScholarWorks at University of Montana

$1-27-2015$

\title{
Low-severity fire increases tree defense against bark beetle attacks
}

Sharon Metzger Hood

University of Montana - Missoula

Anna Sala

University of Montana - Missoula, sala@mso.umt.edu

Emily K. Heyerdahl

USDA Forest Service

Marion Boutin

Universite Toulouse

Follow this and additional works at: https://scholarworks.umt.edu/biosci_pubs

Part of the Biology Commons

Let us know how access to this document benefits you.

\section{Recommended Citation}

Sharon Hood, Anna Sala, Emily K. Heyerdahl, and Marion Boutin 2015. Low-severity fire increases tree defense against bark beetle attacks. Ecology 96:1846-1855. http://dx.doi.org/10.1890/14-0487.1

This Article is brought to you for free and open access by the Biological Sciences at ScholarWorks at University of Montana. It has been accepted for inclusion in Biological Sciences Faculty Publications by an authorized administrator of ScholarWorks at University of Montana. For more information, please contact

scholarworks@mso.umt.edu. 


\title{
Low-severity fire increases tree defense against bark beetle attacks
}

\author{
Sharon Hood, ${ }^{1,4}$ Anna Sala, ${ }^{1}$ Emily K. Heyerdahl, ${ }^{2}$ and Marion Boutin ${ }^{3}$ \\ ${ }^{1}$ University of Montana, Division of Biological Sciences, Missoula, Montana 59812 USA \\ ${ }^{2}$ USDA Forest Service, Rocky Mountain Research Station, Missoula, Montana, 59808 USA \\ ${ }^{3}$ Université Toulouse 3 Paul Sabatier, CNRS, ENFA, UMR5174 Laboratoire Evolution and Diversité Biologique, Toulouse, \\ France F-31062
}

\begin{abstract}
Induced defense is a common plant strategy in response to herbivory. Although abiotic damage, such as physical wounding, pruning, and heating, can induce plant defense, the effect of such damage by large-scale abiotic disturbances on induced defenses has not been explored and could have important consequences for plant survival facing future biotic disturbances. Historically, low-severity wildfire was a widespread, frequent abiotic disturbance in many temperate coniferous forests. Native Dendroctonus and Ips bark beetles are also a common biotic disturbance agent in these forest types and can influence tree mortality patterns after wildfire. Therefore, species living in these disturbance-prone environments with strategies to survive both frequent fire and bark beetle attack should be favored. One such example is Pinus ponderosa forests of western North America. These forests are susceptible to bark beetle attack and frequent, low-severity fire was common prior to European settlement. However, since the late $1800 \mathrm{~s}$, frequent, low-severity fires have greatly decreased in these forests. We hypothesized that non-lethal, low-severity, wildfire induces resin duct defense in $P$. ponderosa and that lack of low-severity fire relaxes resin duct defense in forests dependent on frequent, low-severity fire. We first compared axial resin duct traits between trees that either survived or died from bark beetle attacks. Next, we studied axial ducts using tree cores with crossdated chronologies in several natural $P$. ponderosa stands before and after an individual wildfire and, also, before and after an abrupt change in fire frequency in the 20th century. We show that trees killed by bark beetles invested less in resin ducts relative to trees that survived attack, suggesting that resin duct-related traits provide resistance against bark beetles. We then show low-severity fire induces resin duct production, and finally, that resin duct production declines when fire ceases. Our results demonstrate that low-severity fire can trigger a long-lasting induced defense that may increase tree survival from subsequent herbivory.
\end{abstract}

Key words: bark beetles; dendrochronology; Dendroctonus ponderosae; disturbance; herbivory; Pinus ponderosa; plant defense; resin duct production; tree rings; wildfire.

\section{INTRODUCTION}

Plant survival depends on the ability to accurately sense and respond to environmental cues. In addition to daily and seasonal stress caused by temperature, drought, and nutrient limitation, plants must also cope with periodic disturbance events and attacks by pathogens and herbivores. To survive these biotic and abiotic challenges, plants often use a dynamic array of induced chemical, physical, and mechanical defenses that can also affect subsequent herbivory (Karban and Baldwin 2007). Because disturbance is common in many ecosystems around the world (Pickett and White 1985), abiotic disturbance-mediated induced defense has the potential to greatly impact subsequent herbivory patterns over large landscape scales. For example, hurricanes in-

Manuscript received 11 March 2014; revised 17 December 2014; accepted 18 December 2014; final version received 27 January 2015. Corresponding editor: K. F. Raffa.

${ }^{4}$ E-mail: sharon.hood@umontana.edu creased Conocarpus erectus susceptibility to herbivory (Spiller and Agrawal 2003), and wildfire altered foraging pressure from snowshoe hares and pine squirrels, thus indirectly driving regional-scale variation in tree defense in members of the Pinaceae and Betula species (Smith 1970, Bryant et al. 2009). Additionally, disturbance removal decreased allocation to Acacia defense (Young and Okello 1998). These studies suggest that the frequency and severity of disturbance via physical wounding can affect plant defense and influence response to subsequent herbivory.

Here, we focus on the effects of low-severity wildfire on tree defense against attack by bark beetles. We use the term low-severity wildfire to describe surface fires that burn through the forest, but generally cause little injury or mortality to larger trees (Hood 2010). Wildfire and native bark beetles are dominant disturbance agents in conifer forests of North America, and have interacted for millennia to drive forest composition and structure (McCullough et al. 1998, Parker et al. 2006). However, a 
significant event in the fire history of many western North American forests is the near total cessation of low-severity fires since the late 1800 s due to domestic livestock grazing, road building, a reduction in burning by Native Americans, and organized fire suppression (Pyne 1982). Prior to fire cessation, low-severity surface fires burned frequently ( $<35$ years) over an estimated $34 \%$ of the total land in the United States (Schmidt et al. 2002). This makes coniferous forests an ideal system to study how changes in a large-scale, abiotic disturbance may affect plant resistance to herbivory. Historically, bark beetle and fire interactions have been largely studied from the perspective of disturbance-driven changes in stand structure. This body of research is often contradictory, and important questions remain unanswered (Jenkins et al. 2014). For instance, frequent, low-severity fire maintains low-density stands where surviving trees have more resources available for growth and defense compared to dense stands (Schoennagel et al. 2004), thus potentially increasing resistance to bark beetle attacks (Fettig et al. 2007). However, low- and mixed-severity fires are often followed by pulses in bark beetle attacks that result in additional tree mortality (Hood and Bentz 2007, Davis et al. 2012). Importantly, this pulse is short-lived and little evidence exists that fires lead to bark beetle outbreaks (Lombardero and Ayres 2011, Powell et al. 2012). Non-lethal fire injuries could provide a predictable cue to mount an induced defense to better survive attacks following fire, which may explain these fluctuating patterns of post-fire bark beetle attack success. The ability to sense reliable cues of increased herbivory risk and induce defenses may confer a selective advantage over plants that do not respond effectively to these cues (Karban and Baldwin 2007).

Many phytophagous bark beetles (Coleoptera: Curculionidae, Scolytinae) in the genus Dendroctonus attack and kill healthy host trees in order to reproduce (Raffa and Berryman 1983, Paine et al. 1997). This strategy creates a complex relationship between insect and host tree. Bark beetles attack conifers and bore through the bark into the phloem, where they mate, deposit eggs, and inoculate the tree with fungal symbionts. Larvae feed on phloem as they develop, eventually pupating and becoming adults. This feeding destroys tree transport tissues and kills the host. Trees respond to attacks with constitutive and induced toxic allelochemicals contained in resin that can kill small numbers of attacking beetles. Bark beetles, however, can use tree allelochemicals to produce aggregation pheromones that attract conspecifics, resulting in a coordinated mass attack capable of overwhelming tree defenses (Raffa et al. 2008, Boone et al. 2011).

Conifers, particularly species in the Pinaceae, have evolved high levels of constitutive and induced defenses to survive challenges from bark beetles (Franceschi et al. 2005). Resin stored in constitutive ducts in the secondary xylem is an important component of the defense system, acting first as a physical deterrent against attacking beetles. An interconnected network of axial and radial resin ducts enables resin to flow to an attack or wound site (Lewinsohn et al. 1991). Upon attack, many conifers rapidly alter the chemical composition of resin to become more toxic to bark beetles, compartmentalize symbiotic fungi introduced during attack (Paine et al. 1997, Six and Wingfield 2011), increase de novo resin production, and form axial traumatic resin ducts in secondary xylem to increase connectivity within the resin duct system (Lewinsohn et al. 1991, Hudgins and Franceschi 2004). In pines, where induced ducts have full resin biosynthesis capability (Lewinsohn et al. 1991), induction of resin ducts after wounding would increase resin storage and production capacity available for subsequent attacks. Therefore, resin ducts are likely an important component of pine defense from bark beetles because they are sites of resin storage, synthesis, and delivery. Indeed, resin ducts are positively correlated with resistance to bark beetles in several pine species (Kane and Kolb 2010, Ferrenberg et al. 2014) and to resin flow (Blanche et al. 1992, Rodríguez-García et al. 2014).

Research to date on fire-induced defense in conifers has largely focused on resin flow as a defense trait. Fire increases resin flow in Pinus spp. (Santoro et al. 2001, Wallin et al. 2004, Lombardero et al. 2006, Knebel and Wentworth 2007, Cannac et al. 2009), and this response may last up to four years (Perrakis et al. 2011). The underlying mechanism for this long-term response is unknown, as are the consequences of increased resin flow on post-fire bark beetle attack success. We speculated that frequent, low-severity fire induces defense by increasing axial resin duct production. As opposed to increases in de novo resin flow from preexisting resin ducts, an increase in resin ducts has long-term consequences for defense because they remain functional for years after forming (Lewinsohn et al. 1991). Therefore, trees with more resin ducts should be able to respond to attacks with more resin, due to a larger resin reservoir, and for longer, due to larger biosynthetic capability, compared to trees with fewer ducts. Because trees retain resin ducts in secondary xylem for centuries and proxies of fire occurrence in the form of fire scars allow dating with annual accuracy, the effect of disturbance on tree defense can be reconstructed to compare resin duct characteristics in historical vs. contemporary forests where the frequency of lowseverity fires has greatly decreased. We show that trees that survived mountain pine beetle (Dendroctonus ponderosae Hopkins) attack produced larger axial ducts and invested more in ducts than trees that died from beetle attack. We also show, for the first time, that lowseverity fire increases ponderosa pine (Pinus ponderosa Dougl. ex Laws.) resin duct defense and that resin duct defense is relaxed in the absence of fire. This suggests that frequent, low-severity fire may induce pine resin duct defense to allow a heightened defense response against subsequent bark beetle attacks. 


\section{Methods}

Study sites

We used five sites to address the following questions (see Appendix A for more detailed site descriptions): (1) Are resin ducts a biologically meaningful trait related to tree resistance against bark beetle attack? (2) Does a single, low-severity fire increase ponderosa pine resin ducts? and (3) Does fire frequency affect resin duct defense? To address these questions, we used increment cores collected either for this study (Lubrecht and Montana sites) or available from previous fire history studies (Idaho, Oregon, and Utah sites; Keeling et al. 2006, Heyerdahl et al. 2008, 2011, 2014) to measure axial resin ducts. Increment cores, cylinders of wood 4-5 $\mathrm{mm}$ in diameter, spanning from the bark to roughly the pith, were extracted manually with an increment borer to yield a cross section containing annual tree rings. We used these cores to quantify annual tree growth and resin duct production. Cores were collected at approximately $1.37 \mathrm{~m}$ above the ground at the Lubrecht and Montana sites, at $15 \mathrm{~cm}$ from the Utah and Oregon sites, and at $50 \mathrm{~cm}$ from the Idaho site. Reconstructing historical fire regimes from tree rings is extremely time intensive. Therefore, using these samples allowed us to choose sites with fire history that included frequent fire followed by a period of fire cessation from which crossdated cores were already available. General details on fire history reconstruction can be found in Falk et al. (2011).

\section{Data collection}

Are resin ducts related to tree resistance against bark beetles?-To test whether resin ducts are related to tree resistance against bark beetles, we sampled ponderosa pine in the University of Montana's Lubrecht Experimental Forest in 2013 in an area with recent mountain pine beetle activity (Appendix A). Beetle activity in the area was high, with between $40 \%$ and $72 \%$ of ponderosa pine in nearby long-term tree monitoring plots mass attacked and killed between 2005 and 2012. Average tree diameter of mass-attacked trees was $29.5 \mathrm{~cm}$ (S. Hood, unpublished data). We collected two, $4.5 \mathrm{~mm}$ increment cores from each of 15 randomly located pairs of beetleattacked trees (one that survived and one that died) in unburned stands with no recent history of harvesting. Paired trees were within $10 \mathrm{~m}$ and similar in diameter (within $\pm 2.5 \mathrm{~cm}$, measured at $1.4 \mathrm{~m}$ height). Cored trees had evidence of beetle attack (i.e., pitch tubes), but attack density at the time of sampling varied. All dead trees were mass attacked, with copious amounts of pitch tubes and red or fading needles. Unsuccessfully attacked trees had between 5 and $50+$ pitch tubes, but had healthy phloem and needles, indicating beetles had attempted to attack the tree, but were not successful. Subsequent crossdating showed all successful attacks occurred between 2008 and 2011.
Do resin ducts increase after one fire?-We used the Montana and Utah sites to determine if resin ducts increase after fire (Appendix A). The Montana site included an area that burned in a 2003 wildfire. There is no record of prior wildfire at this site for at least 100 years (Gibson and Morgan 2009). In fall 2011, eight full growing seasons after wildfire, we collected $5 \mathrm{~mm}$ wide cores from 19 trees within the burn perimeter and also from eight unburned trees growing less than $100 \mathrm{~m}$ outside of the burned area. The trees inside the burned area were part of a previous study (Davis et al. 2012), and were known to have survived the fire. At the Utah site, the majority of trees established between 1850 and 1860 after an 1841 wildfire (WUN plot $15 \mathrm{C}$ in Heyerdahl et al. [2011]). The next and last wildfire occurred in 1899. We selected one, $4 \mathrm{~mm}$ wide core from each of seven trees that had formed a fire scar during the 1899 fire and seven trees that had no scar (i.e., no direct fire wounding).

Does fire frequency affect resin duct defense?-We used the Idaho and Oregon sites to determine if resin duct production declined after fires ceased locally, which we identified as the date of the last recorded fire at each site (Appendix A). Although we lack information on the precise local causes of these abrupt decreases in fire frequency, they are clearly evident in the fire-scar record (Heyerdahl et al. 2008, 2014). The Idaho site (called site MB in Keeling et al. [2006]; but COV in Heyerdahl et al. [2008]) historically sustained frequent, low-severity fires that occurred every 18 years on average (range 3 to 46 years) over a 12-ha area from 1663 to 1919 . At this site, we had $5 \mathrm{~mm}$ wide cores available from two stands (eight cores per stand) with similar physiography and fire history until a fire in 1919. After this time, there were no fires in one stand, but the other stand burned in 1960 and 1987. This allowed us to compare resin ducts between stands with and without fire since 1919. The Oregon site (LYT plot 18C; Heyerdahl et al. 2014) historically sustained frequent, low-severity fires that occurred every 12 years on average (range 6-18 years) over a 0.15 -ha area from 1650 to 1864 . The last fire occurred in 1864 . We selected all $4 \mathrm{~mm}$ wide cores collected from trees in the plot with at least 75 years of growth before fires ceased ( $n=7$ cores).

Core preparation and measurement.-We prepared cores using standard techniques (mounted and sanded until cellular structure was visible through a binocular microscope) and assigned the correct calendar year to each tree ring (i.e., crossdated; Grissino-Mayer 2001). The cores we obtained from existing studies were prepared similarly (Keeling et al. 2006, Heyerdahl et al. 2008, 2011, 2014). We measured ring widths of all cores to the nearest $0.001 \mathrm{~mm}$ using an Acu-Gage micrometer and Measure J2X software version 3.1 (Voortech Consulting, Hudson, New Hampshire, USA). We scanned all cores using an Epson platform scanner (Epson America, Long Beach, California, USA) at $1200 \mathrm{dpi}$ for processing in ImageJ version 1.46r (U.S. 
National Institutes of Health, Bethesda, Maryland, USA). We measured axial resin duct size to the nearest $1 \times 10^{-7} \mathrm{~mm}^{2}$ using the ellipse tool and noted the calendar year in which each duct formed.

We calculated five resin duct metrics for each core. Three of these metrics capture annual absolute investment in resin ducts, unadjusted for ring area mean duct size, calculated as the mean size of all ducts per annual ring $\left(\mathrm{mm}^{2}\right)$; duct production, calculated as the total number of ducts per annual ring (no./yr); and total duct area calculated as the sum of duct area per annual ring $\left(\mathrm{mm}^{2} / \mathrm{yr}\right)$. The other two metrics capture the annual investment in resin ducts relative to ring area duct density, calculated by dividing duct production (ducts. $\mathrm{mm}^{-2} \cdot \mathrm{yr}^{-1}$ ) by ring area (ring width $\times$ core diameter); and relative duct area calculated by dividing total duct area by ring area and multiplying by 100 (percentage of annual ring; see Appendix A for years measured by site).

\section{Data analysis}

We compared resin duct metrics and ring width between paired susceptible and resistant trees $(n=15$ pairs) at the Lubrecht site based on measurements from the most recent 30 years available (1981-2010). All susceptible trees died between 2009 and 2012, with 9 of 15 trees dying in 2011. Attacks occurred one year prior to death. The last common year of growth for most trees was 2010; therefore, we excluded rings produced after 2010 from the analysis. Resin duct area and production values from the same tree were summed by year to reduce incidence of zeros in the dataset, while ring width values were averaged.

Resin duct production is variable and positively correlated with summer temperature and precipitation (Rigling et al. 2003). Therefore, we examined resin duct variation over time and response time post-fire by calculating departures from average relative resin duct area eight years before and after the single fires at the Montana and Utah sites. For each tree, we calculated the annual departure of total relative resin duct area, where positive departures indicate an increase in duct area for that year compared to the 16-year core average. Based on our departure analysis, we then compared total resin duct area before and after the single fires.

To compare resin duct production associated with changes in fire frequency, we measured resin ducts each year for the entire available time span (1663-2006) from 16 trees at the Idaho site and compared periods before and after the last common fire in 1919 (eight trees from each stand). At the Oregon site, we measured resin ducts each year from seven trees 75 years before and after the last recorded fire in 1864 (time span 1795-1944). At both sites, we included the five years following the last fire recorded before fires ceased to account for any potential fire effect on resin ducts.

We used general linear mixed models for all analyses (SAS 9.3; SAS Institute, Cary, North Carolina, USA) and applied a zero-adjustment for rings without ducts using a log-link function after Stahel (2002). We standardized resin duct area and duct production results to $5 \mathrm{~mm}$ wide core diameters to aid in comparisons between sites. Ring area was used as a covariate in models comparing duct size, total duct area, and duct production to account for correlations between ducts and growth, but not in models of resin duct density and relative duct area, as these variables were already standardized to ring area. Individual trees were the experimental unit. We used a lognormal distribution to stabilize residuals for all variables except duct size, which was normally distributed. Lognormal model estimates were back-transformed for the purpose of reporting mean and standard error. Pairwise differences in categorical variables were tested using Tukey's post hoc test (significance level $\alpha<0.05$, one-tailed test).

Total duct area and ring width were strongly and positively correlated at each site, suggesting a common influence of climate on both variables (Fritts 1976, Rigling et al. 2003). Therefore, we investigated the role of climate in resin duct production apart from any effect of fire. For this analysis, we used the most recent 30 rings (after 1980, the period of instrumental data) on cores from Idaho, Montana, and Oregon, plus seven cores from younger trees at the Oregon site. Utah data was excluded from analysis, as we did not have resin duct data for this time period. We used PRISM climate data to relate climate to total resin duct area (data available online). ${ }^{5}$ Annual monthly total precipitation (PPT; mm), maximum temperature $\left(T_{\max } ;{ }^{\circ} \mathrm{C}\right)$ and 1981-2010 30-year normal PPT and $T_{\max }$ were used in the analysis. We used July climate data, as that was the month showing most significant correlations between total resin duct area, PPT, and $T_{\max }$ (data not shown) and also because midsummer is typically when the transition to latewood begins as trees become water stressed. Resin ducts are typically found in the earlywood-latewood transition and latewood (Rigling et al. 2003); therefore, conditions in July will likely affect resin duct production. We calculated departure from 30 year normal July PPT and $T_{\max }$ by subtracting the 30 year normal values from yearly data. We used mixed model analysis to examine total resin duct area as a function of departure from 30-year normal July PPT and $T_{\max }$.

\section{RESUlts}

Are resin ducts related to tree resistance against bark beetles?-Tree ring area was positively related to duct size, total duct area, and duct production, and was a significant covariate in the models for each of these variables $(P<0.0001$; Appendix B). After accounting for ring area, trees that survived bark beetle attack had produced approximately $20 \%$ larger ducts $\left(F_{1,14}=18.25\right.$, $P=0.0004$ ) during the previous 30 years than trees that

\footnotetext{
${ }^{5}$ http://prismmap.nacse.org/nn/
} 

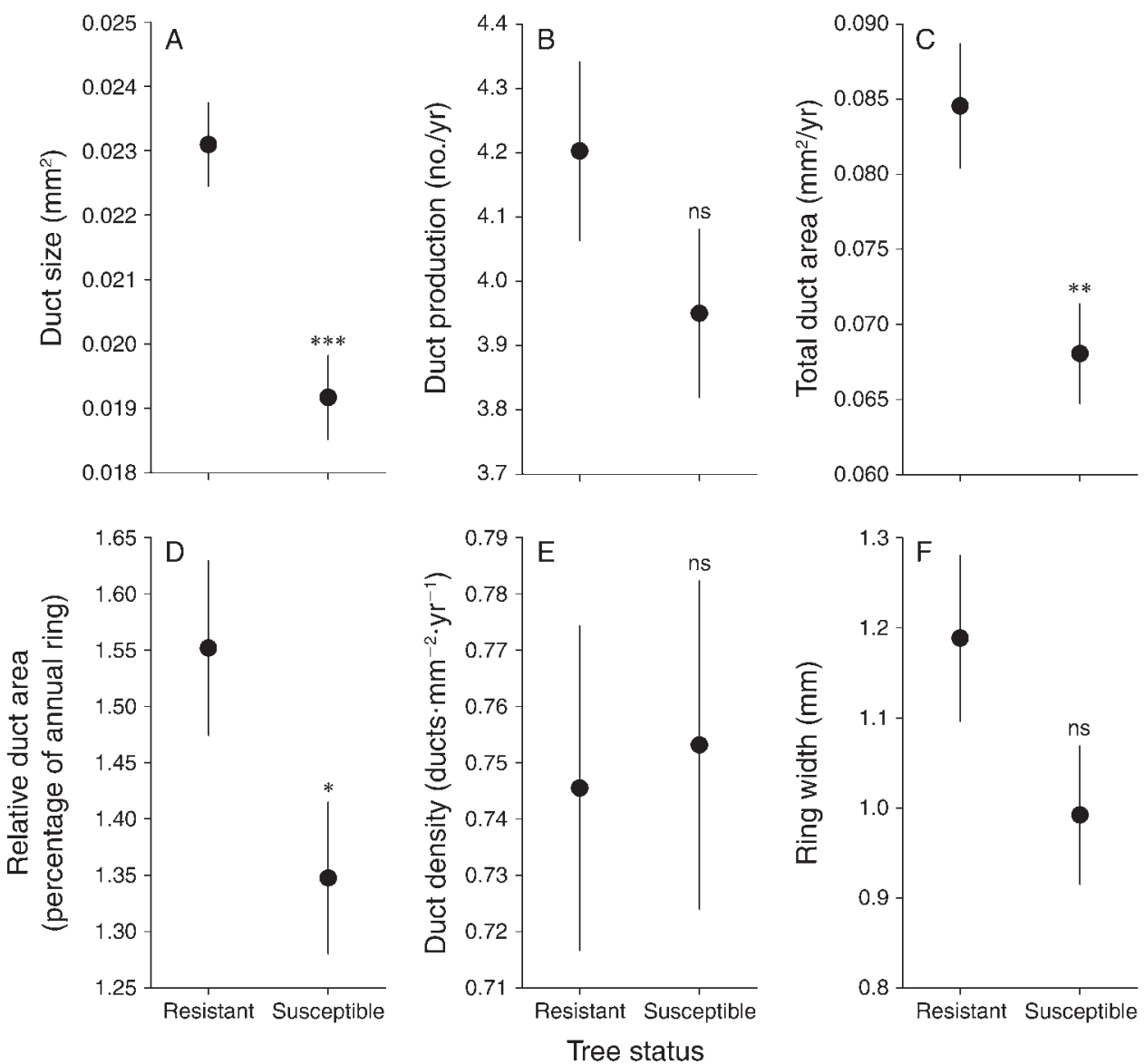

FIG. 1. (A-E) Axial resin duct properties and (F) ring width (mean \pm SE) of resistant vs. susceptible ponderosa pine based on the most recent, common, 30 calendar years of tree growth (1981-2010). Susceptible trees were successfully attacked by mountain pine beetle between 2008 and 2011 and killed, while resistant trees survived the attack. One-tailed significance values indicate susceptible trees have lower duct properties compared to resistant trees. A, B, and C are adjusted means after accounting for ring area as a covariate based on a $5 \mathrm{~mm}$ core diameter. $\mathrm{D}$ and $\mathrm{E}$ are standardized to ring area; therefore, ring area was not a covariate in the model.

$* P<0.05 ; * * P<0.01 ; * * * P<0.001 ;$ ns, not significant.

died from attack (Fig. 1A; Appendix B). In addition, resistant trees had approximately $24 \%$ more resin duct area per ring and had allocated $15 \%$ more area to ducts than susceptible trees (total duct area, $F_{1,14}=9.83, P=$ 0.0037; relative duct area, $F_{1,14}=4.01, P=0.0325$; Fig. $1 \mathrm{C}-\mathrm{D})$. Trees did not differ in duct production $\left(F_{1,14}=\right.$ 1.75, $P=0.1038$; Fig. 1B; Appendix B) after accounting for ring area or in duct density $\left(F_{1,14}=0.03, P=0.4274\right.$; Fig. 1E). In the 30 years before attack, surviving trees tended to grow faster than trees killed by beetles, with approximately $20 \%$ wider ring widths than susceptible trees $\left(F_{1,14}=2.71, P=0.061\right.$; Fig. $\left.1 \mathrm{~F}\right)$.

Do resin ducts increase after one fire? - Based on our departure analysis, we compared total resin duct area one year before and after the fire for the Montana site and two years before and after the fire for the Utah site (Fig. 2). Total resin duct area was $80 \%$ greater after fire at the Montana site (fire $\times$ time, $F_{1,25}=7.45, P=0.0115$ ) and $87 \%$ greater at the Utah site (fire, $F_{1,12}=3.6, P=$
0.0071), after accounting for ring area (Fig. 2 insets; Appendix C). Patterns of increase following fire were similar at both sites, but timing of response differed slightly (Fig. 2). There was considerable interannual variability at both sites, but the departure direction for the burned and unburned trees was generally in agreement for all years, except after fire. At the Montana site, burned trees had the greatest duct area one year after fire and returned to unburned tree levels the next year, whereas the unburned, control trees showed no corresponding increase. Burned trees at the Utah site showed a two year increase in total resin duct area before returning to unburned tree levels. However, resin duct area the first year post-fire did not differ from unburned tree levels.

Total duct area was positively related to precipitation $\left(F_{1,65}=15.68, P=0.0002\right)$ and maximum temperature $\left(F_{1,65}=12.79, P=0.0007\right)$ departure from 1981-2010 30-year July normal values (Appendix C), with total 

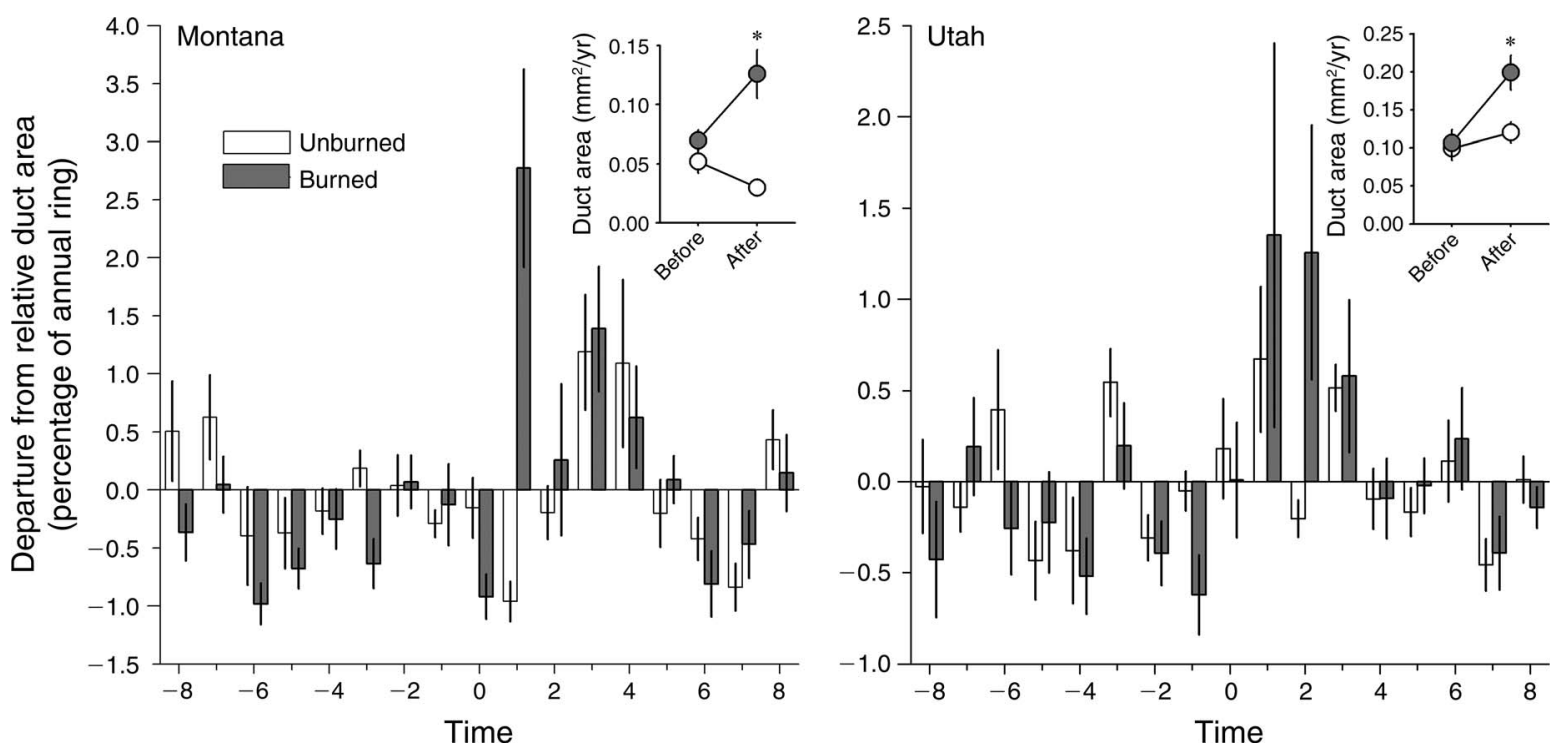

FIG. 2. Departure (mean $\pm \mathrm{SE}$ ) from average total axial resin duct area by year for burned and unburned ponderosa pine trees at Montana and Utah sites. Fire occurrence is denoted as time $=0$; negative values are years before fire and positive values are years after fire. Insets show total resin duct area (adjusted mean $\pm \mathrm{SE}$ ) after accounting for ring area based on $5 \mathrm{~mm}$ wide samples. Inset for the Montana site total duct area is one year before and after fire, and inset for the Utah site total duct area is the second year before and after fire. An asterisk (*) indicates duct area increased after fire on burned trees.

duct area per ring increasing with warmer and wetter conditions.

Does fire frequency affect resin duct defense?-Duct area decreased by approximately $15 \%$ in the period after fires ceased at both the Idaho $\left(F_{1,14}=10.6, P=0.0057\right)$ and Oregon $\left(F_{1,4}=10.07, P=0.0338\right)$ sites (Appendix B). At the Idaho site with no fire since 1919, duct area declined after fire ceased (Fig. 3; $P=0.0027$ ), whereas, at the site that continued to burn throughout the 20th century, there was no change in duct area between the two periods (Fig. 3; $P=0.9854$ ). Duct area also declined in the years following fire cessation at the Oregon site $(P$ $=0.0338)$. Ring area was a significant covariate in explaining duct area at both sites (Idaho site, $F_{1,4795}=$ 1177.47, $P<0.0001$; Oregon site, $F_{1,871}=68.79, P<$ 0.0001; Appendix C).

\section{DisCUSSION}

Our results indicate that resin duct characteristics are related to tree resistance against bark beetle attack. Trees that died from beetle attack had smaller axial resin ducts that occupied a lower percentage of ring area relative to trees that survived the attack. This difference was consistent for 30 years prior to attack. Because ducts remain functional for years and synthesize, store, and conduct resin (Lewinsohn et al. 1991), increases in allocation to ducts results in a long-term increase in a tree's defense capacity against bark beetle attack. Resin ducts are under strong genetic control, but are also a plastic trait influenced by climate and wounding, as shown here and by others (Rigling et al. 2003, Rosner and Hannrup 2004, Rodríguez-García et al. 2014).
However, we note that the relationship between resin duct anatomy and resin flow is not fully understood, and flow is likely also influenced by additional factors, such as radial resin ducts (Rodríguez-García et al. 2014), not measured in this study.
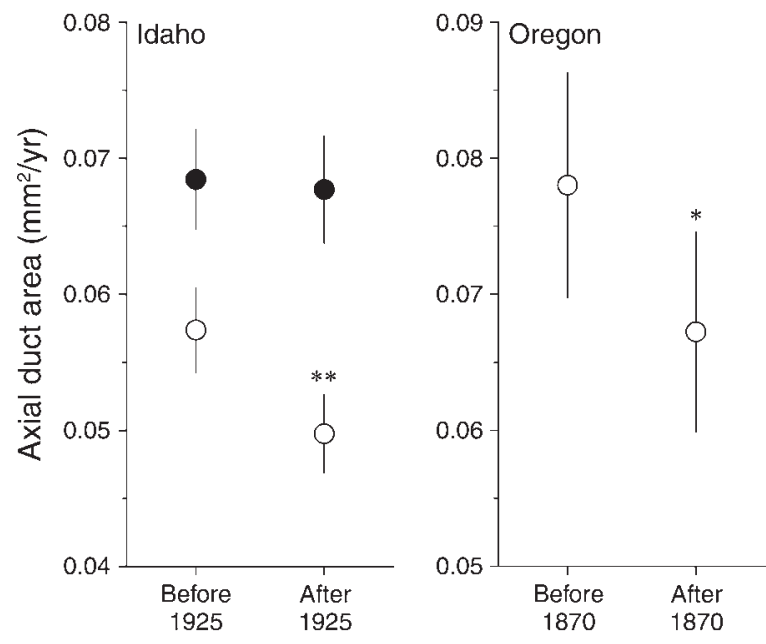

Fire cessation period

FIG. 3. Ponderosa pine axial resin duct area (adjusted mean $\pm \mathrm{SE}$ ) before and after fire cessation in Idaho and Oregon after accounting for ring area based on a $5 \mathrm{~mm}$ core diameter. We defined fire cessation as the period following the last recorded fire at a site, determined from tree-ring reconstructions. The Idaho site was divided into two areas: open circles are fires that ceased in the 20th century, solid circles are fires that continued in the 20th century. Asterisks (*) indicate duct area decreased after fire exclusion after 1870 in Oregon and after 1925 in Idaho.

* $P<0.05 ; * * P<0.01$. 


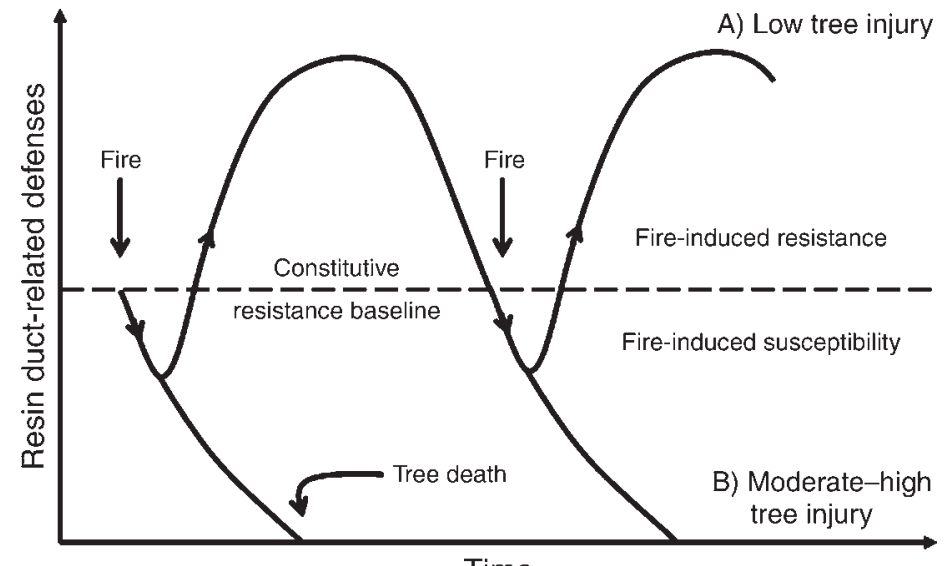

Time
FIG. 4. Hypothesized conceptual model of fire-induced resin duct-related defenses (e.g., resin ducts, flow, and chemistry) in conifers. (A) For trees with low levels of injury, fire causes a brief (days, up to 1 growing season) reduction in resistance to bark beetle attacks (i.e., fire-induced susceptibility) before induced resin ducts form, followed by a period of increased resistance that lasts for several years (i.e., fire-induced resistance) before returning to constitutive levels as induced resin ducts lose connectivity due to annual tree growth. The exact timing and magnitude of this switch is dependent on the specific bark beetle and tree species involved, growing season length, and post-fire climate. (B) Fire increases susceptibility to attack for trees with moderate to high levels of injury and the probability of tree death. Additional research is needed to understand how defense components interact to affect overall fire-induced tree resistance.
Our results generally support those of Kane and Kolb (2010) and Ferrenberg et al. (2014), who found a positive association between resin ducts and tree survival in ponderosa pine, limber pine (Pinus flexilis James), and lodgepole pine ( $P$. contorta Douglas ex Louden). Though these studies reported positive correlations between growth and resin duct production and area, they did not account for ring area when reporting resin duct differences between susceptible and resistant trees. This makes direct comparisons with our study difficult and highlights the need to develop standardized methodology and reporting of resin duct characteristics. Our results go a step further than Kane and Kolb (2010) by pairing attacked resistant and susceptible trees of close proximity and similar size. This reduced potential confounding factors of tree location and size that can influence beetle host selection and behavior (Boone et al. 2011) and ensured that survival was not due to lower likelihood of attack.

Resin duct production was positively related to tree growth for all our sites, suggesting that faster growing trees are more resistant to bark beetles (Appendix B and C). Resistant trees tended to have faster growth (Fig. 1F) and invested more per unit area of xylem in resin ducts compared to susceptible trees (Fig. 1D). Kane and Kolb (2010) also found resin duct properties were more important than tree growth for predicting resistance to bark beetles. Several studies have reported positive correlations between resin ducts and tree growth (Rigling et al. 2003, Rosner and Hannrup 2004, Kane and Kolb 2010, Ferrenberg et al. 2014, Rodríguez-García et al. 2014 ) and between resin yield and growth (Roberds et al. 2003, McDowell et al. 2007). These results suggest that faster growing trees may be more resistant to bark beetles, but, as we show, variation in resin duct properties also greatly influences tree resistance.

We show for the first time that low-severity fire correlates with increased resin duct defenses in ponderosa pine and that these defenses declined when fires ceased. We suggest this fire-caused stimulation of resin ducts is similar to systemic induced resistance (SIR; Bonello et al. 2006, Eyles et al. 2010) and results in increased tree survival from bark beetle attack by increasing the potential for resin synthesis and storage in resin ducts (Fig. 4). SIR is a welldefined plant response involving specific defense signaling responses, in which a stimulus amplifies dormant signaling proteins and leads to priming and a more rapid defense response to subsequent attack (Koornneef and Pieterse 2008, Conrath 2011). However, it is not known if fireinduced resistance involves the same signaling mechanisms as SIR and to what degree the response is truly systemic, as opposed to localized to the tree bole. Our results suggest that, in forested ecosystems with frequent, low-severity fire regimes, fire-induced resistance may serve to increase defense against bark beetle attack in the long term. In this way, trees exposed to fire are better able to survive bark beetle attacks if injury levels are low (Lombardero et al. 2006, Kane and Kolb 2010).

In trees with moderate levels of fire-caused injuries, fire-induced susceptibility may increase mortality from bark beetles (Fig. 4). Indeed, immediately following fire, bark beetle-caused tree mortality can be substantial, up to $25 \%$ tree mortality beyond the direct effects of fire (Hood and Bentz 2007), and trees with moderate injury levels were more likely to be mass attacked and killed by beetles compared to trees with low and high injury levels (Davis et al. 2012). Trees with low injuries can quickly mount a defense response. In contrast, high levels of crown scorch and basal cambium kill resulting from mixed- and highseverity fires can limit phloem transport, photosynthetic potential, and reduce resources necessary for compartmentalizing basal wounds and mounting an energetically demanding defense response. These trees with high injury are also poor hosts for bark beetle development, due to low substrate quality (Powell et al. 2012). The pulse of bark beetle mortality after fire is typically short-lived, persisting only one or two years (Lombardero and Ayres 2011, Davis et al. 2012, Powell et al. 2012). We know of no study showing a long-term bark beetle population 
increase attributable to fire. This is likely due to a combination of a depletion of susceptible host trees within one to two years after fire and a decline in beetle attack success in trees with fire-induced resistance.

Studies of post-fire tree mortality and bark beetle interactions have also found similar patterns of fireinduced susceptibly followed by fire-induced resistance (Lombardero et al. 2006, Knebel et al. 2008, Lombardero and Ayres 2011). For instance, fire can alter induced resin composition (Powell and Raffa 2011) and temporarily decrease resin flow prior to subsequent increases above pre-fire levels (Lombardero et al. 2006, Lombardero and Ayres 2011). In trees with low levels of fire-caused injury, increases in resin ducts and resin flow, combined with declines in attack success, also suggest a switch from increased susceptibility to increased resistance. Indeed, there is widespread evidence of increased long-term resin flow after fire in several pine species (Santoro et al. 2001, Wallin et al. 2004, Lombardero et al. 2006, Knebel and Wentworth 2007, Cannac et al. 2009, Perrakis et al. 2011). The exact timing of this switch depends on the specific bark beetle and tree species involved, growing season length, and post-fire climate. Initial increases in resin flow could occur by de novo resin synthesis in existing ducts and then continue to increase if fire increases resin ducts, as axial resin duct density is positively related to resin flow (Blanche et al. 1992). Therefore, because resin ducts remain functional for years and provide more sites for resin production and storage, the one- or two-year increase in resin ducts after fire that we report is consistent with the long-term increase in resin flow found in previous studies. Rodríguez-García et al. (2014) reported an increase in axial resin ducts after tapping for resin collection in maritime pine (Pinus pinaster Aiton) and suggested that this response in pines is a form of SIR.

There was a difference in timing of resin duct increase after fire between the Montana and Utah sites. These site differences may be due to differences in fire-caused tree injury and in post-fire climate. We had detailed records of fire occurrence immediately after the fire at the Montana site, but not at the Utah site. The Utah site burned in 1899 , making it impossible to know exactly which trees burned within the fire perimeter and the extent of tree injury. While the unburned trees had no fire scars, fire may have burned around some of the trees and stimulated resin duct production without killing cambium, thus causing the increase in ducts in unburned trees one year post fire. Potentially higher wounding levels at the Utah site could have limited wood growth and resin duct formation immediately after a fire, thus, delaying response time. Post-fire climate may also have influenced tree response time. At both sites, the induction response occurred the year when precipitation, which has been shown to enhance resin duct production (Rigling et al. 2003), was near normal. Annual precipitation at the Montana site was near average one and two years post-fire. At the Utah site, one year post-fire was the eighth driest year on record
(1895-2012; PRISM Data Explorer, see footnote 5), while the second year post-fire had near normal precipitation.

Increased resin duct production after fire is likely a direct response to wounding by fire. However, changes in microclimate due to frequent, low-severity fire may also enhance resin duct production via changes in stand structure. Low-severity fire reduces tree density, which reduces water stress in surviving trees, and increases temperatures due to increased solar radiation (Sala et al. 2005). Consistent with the results of Rigling et al. (2003), we found that resin duct area was positively correlated with both warmer and wetter conditions and with ring width. Therefore, increases in tree radial growth in response to higher water availability (Fritts 1976), combined with warmer temperatures may also further stimulate resin duct production beyond the effects of fire alone. While favorable environmental conditions may increase duct production, they do not explain the sharp spike in resin ducts observed immediately after fire in our study. Changes in stand structure after fire persist for years. Therefore, if these changes were driving the observed increase in resin ducts, we would predict a persistent increase in resin ducts over time rather than the spike after fire we observed. Additional research is needed on both pre-fire and post-fire climate and fire severity feedbacks on resin duct production. Fire severity is increasing in some regions due to climate change (van Mantgem et al. 2013). Severe water stress before or after fire may impair tree growth and wound repair, leading to higher tree mortality either due to direct effects of the fire or subsequent bark beetle attacks, which are also impacted by changes in climate (Bentz et al. 2010).

Knowledge of the effects of low-severity fire on tree defense and ensuing stand susceptibility to bark beetle attack is important not only to increase our understanding of the ecological role of frequent fire, but, also, because of its management implications. As a result of decades without fire, uncharacteristically high stand densities are now common in many fire-dependent forests, such as the low elevation ponderosa pine forests studied here (Keeling et al. 2006, Ryan et al. 2013). Recent increases in fire severity and bark beetle outbreaks have been attributed to these high stand densities (Raffa et al. 2008, Stephens et al. 2009). This, in turn, has spurred efforts to reduce stand densities and lower the probability of high-severity wildfire in forests that historically sustained low-severity fire regimes, primarily through mechanical thinning, sometimes followed by prescribed burning. Our results suggest that low-severity fire may trigger a long-term induced defense via increases in resin ducts. These findings suggest that excluding fire from forests that historically sustained frequent, low-severity fire regimes might lead to increased bark beetle attack success due to a relaxation of tree defenses. Therefore, the long-term outcomes of burning and thinning may differ as the benefits of thinning alone are limited to those mediated via changes in stand structure and tree physiology, but exclude 
potential direct effects of fire on tree defense. Because tree resistance depends on a complex suite of defense traits based on resin flow, chemical composition, and ducts, additional research on the components of our conceptual model of fire-induced conifer resistance is needed to determine if fire-induced resin duct defense increases long-term post-fire tree survival and standlevel resistance against bark beetles. While our study only examines the effect of fire on ponderosa pine, our findings may extend to those other conifer ecosystems where disturbance is dominated by frequent, lowseverity fire and native bark beetles. Our results highlight the need to understand how and by which mechanisms specific disturbances influence long-term tree defense and resistance to bark beetles.

\section{ACKNOWLEDGMENTS}

Funding for this work was provided by the USDA Forest Service, Rocky Mountain Research Station, Fire, Fuel, and Smoke Science Program. Partial support for A. Sala was provided by McIntire-Stennis Cooperative Forestry Research Grant MONZ-1206 from the College of Forestry and Conservation of the University of Montana. We thank Eric Keeling for providing increment cores, Elaine Kennedy-Sutherland for sharing scanning equipment, Francisco Lloret for help with data collection and analytical advice, and Scott Baggett for statistical advice. We also thank Barbara Bentz, John Maron, and three anonymous reviewers for providing comments on previous versions of the manuscript.

\section{Literature Cited}

Bentz, B. J., J. Regniere, C. J. Fettig, E. M. Hansen, J. L. Hayes, J. A. Hicke, R. G. Kelsey, J. F. Negron, and S. J. Seybold. 2010. Climate change and bark beetles of the western United States and Canada: direct and indirect effects. BioScience 60:602-613.

Blanche, C. A., P. L. Lorio, R. A. Sommers, J. D. Hodges, and T. E. Nebeker. 1992. Seasonal cambial growth and development of loblolly pine: xylem formation, inner bark chemistry, resin ducts, and resin flow. Forest Ecology and Management 49:151-165.

Bonello, P., T. R. Gordon, D. A. Herms, D. L. Wood, and N. Erbilgin. 2006. Nature and ecological implications of pathogen-induced systemic resistance in conifers: a novel hypothesis. Physiological and Molecular Plant Pathology 68: 95-104.

Boone, C. K., B. H. Aukema, J. Bohlmann, A. L. Carroll, and K. F. Raffa. 2011. Efficacy of tree defense physiology varies with bark beetle population density: a basis for positive feedback in eruptive species. Canadian Journal of Forest Research 41:1174-1188.

Bryant, John P., et al. 2009. Fire drives transcontinental variation in tree birch defense against browsing by snowshoe hares. American Naturalist 174:13-23.

Cannac, M., T. Barboni, L. Ferrat, A. Bighelli, V. Castola, J. Costa, D. Trecul, F. Morandini, and V. Pasqualini. 2009. Oleoresin flow and chemical composition of Corsican pine (Pinus nigra subsp. laricio) in response to prescribed burnings. Forest Ecology and Management 257:1247-1254.

Conrath, U. 2011. Molecular aspects of defence priming. Trends in Plant Science 16:524-531.

Davis, R. S., S. Hood, and B. J. Bentz. 2012. Fire-injured ponderosa pine provide a pulsed resource for bark beetles. Canadian Journal of Forest Research 42:2022-2036.

Eyles, A., P. Bonello, R. Ganley, and C. Mohammed. 2010. Induced resistance to pests and pathogens in trees. New Phytologist 185:893-908.
Falk, D. A., E. K. Heyerdahl, P. M. Brown, C. Farris, P. Z. Fulé, D. McKenzie, T. W. Swetnam, A. H. Taylor, and M. L. Van Horne. 2011. Multi-scale controls of historical forest-fire regimes: new insights from fire-scar networks. Frontiers in Ecology and the Environment 9:446-454.

Ferrenberg, S., J. Kane, and J. Mitton. 2014. Resin duct characteristics associated with tree resistance to bark beetles across lodgepole and limber pines. Oecologia 174:1283-1292.

Fettig, C. J., K. D. Klepzig, R. F. Billings, A. S. Munson, T. E. Nebeker, J. F. Negrón, and J. T. Nowak. 2007. The effectiveness of vegetation management practices for prevention and control of bark beetle infestations in coniferous forests of the western and southern United States. Forest Ecology and Management 238:24-53.

Franceschi, V. R., P. Krokene, E. Christiansen, and T. Krekling. 2005. Anatomical and chemical defenses of conifer bark against bark beetles and other pests. New Phytologist 167:353-376.

Fritts, H. 1976. Tree rings and climate. Academic Press, London, UK.

Gibson, C. E., and P. Morgan. 2009. Atlas of digital polygon fire extents for Idaho and western Montana. USDA Forest Service, Rocky Mountain Research Station, Fort Collins, Colorado, USA.

Grissino-Mayer, H. D. 2001. Evaluating crossdating accuracy: a manual and tutorial for the computer program COFECHA. Tree Ring Research 57:205-221.

Heyerdahl, E. K., P. M. Brown, S. Kitchen, and M. H. Weber. 2011. Multicentury fire and forest histories at 19 sites in Utah and eastern Nevada. General Technical Report RMRSGTR-261WWW. USDA Forest Service, Rocky Mountain Research Station, Fort Collins, Colorado, USA.

Heyerdahl, E. K., D. A. Falk, and R. A. Loehman. 2014. Data archived with the International Multiproxy Paleofire Database, IGBP PAGES/World Data Center for Paleoclimatology. NOAA/NCDC Paleoclimatology Program, Boulder, Colorado, USA.

Heyerdahl, E. K., P. Morgan, and J. P. Riser. 2008. Crossdated fire histories (1650-1900) from ponderosa pine-dominated forests of Idaho and western Montana. General Technical Report RMRS-GTR-214WWW. USDA Forest Service, Rocky Mountain Research Station, Fort Collins, Colorado, USA.

Hood, S. M. 2010. Mitigating old tree mortality in longunburned, fire-dependent forests: a synthesis. General Technical Report RMRS-GTR-238. USDA Forest Service, Rocky Mountain Research Station, Fort Collins, Colorado, USA.

Hood, S. M., and B. Bentz. 2007. Predicting post-fire Douglasfir beetle attacks and tree mortality in the Northern Rocky Mountains. Canadian Journal of Forest Research 37:10581069.

Hudgins, J. W., and V. R. Franceschi. 2004. Methyl jasmonateinduced ethylene production is responsible for conifer phloem defense responses and reprogramming of stem cambial zone for traumatic resin duct formation. Plant Physiology 135:2134-2149.

Jenkins, M. J., J. B. Runyon, C. J. Fettig, W. G. Page, and B. J. Bentz. 2014. Interactions among the mountain pine beetle, fires, and fuels. Forest Science 60:489-501.

Kane, J., and T. Kolb. 2010. Importance of resin ducts in reducing ponderosa pine mortality from bark beetle attack. Oecologia 1-9.

Karban, R., and I. T. Baldwin. 2007. Induced responses to herbivory. University of Chicago Press, Chicago, Illinois, USA.

Keeling, E. G., A. Sala, and T. H. DeLuca. 2006. Effects of fire exclusion on forest structure and composition in unlogged ponderosa pine/Douglas-fir forests. Forest Ecology and Management 237:418-428.

Knebel, L., D. J. Robison, T. R. Wentworth, and K. D. Klepzig. 2008. Resin flow responses to fertilization, wounding and fungal inoculation in loblolly pine (Pinus taeda) in North Carolina. Tree Physiology 28:847-853. 
Knebel, L., and T. R. Wentworth. 2007. Influence of fire and southern pine beetle on pine-dominated forests in the Linville Gorge Wilderness, North Carolina. Castanea 72:214-225.

Koornneef, A., and C. M. Pieterse. 2008. Cross talk in defense signaling. Plant Physiology 146:839-844.

Lewinsohn, E., M. Gijzen, and R. Croteau. 1991. Defense mechanisms of conifers: differences in constitutive and wound-induced monoterpene biosynthesis among species. Plant Physiology 96:44-49.

Lombardero, M. J., and M. P. Ayres. 2011. Factors influencing bark beetle outbreaks after forest fires on the Iberian Peninsula. Environmental Entomology 40:1007-1018.

Lombardero, M. J., M. P. Ayres, and B. D. Ayres. 2006. Effects of fire and mechanical wounding on Pinus resinosa resin defenses, beetle attacks, and pathogens. Forest Ecology and Management 225:349-358.

McCullough, D. G., R. A. Werner, and D. Neumann. 1998. Fire and insects in northern and boreal forest ecosystems of North America. Annual Review of Entomology 43:107-127.

McDowell, N. G., H. D. Adams, J. D. Bailey, and T. E. Kolb. 2007. The role of stand density on growth efficiency, leaf area index, and resin flow in southwestern ponderosa pine forests. Canadian Journal of Forest Research 37:343-355.

Paine, T. D., K. F. Raffa, and T. C. Harrington. 1997. Interactions among Scolytid bark beetles, their associated fungi, and live host conifers. Annual Review of Entomology 42:179-206.

Parker, T. J., K. M. Clancy, and R. L. Mathiasen. 2006. Interactions among fire, insects and pathogens in coniferous forests of the interior western United States and Canada. Agricultural and Forest Entomology 8:167-189.

Perrakis, D. D. B., J. K. Agee, and A. Eglitis. 2011. Effects of prescribed burning on mortality and resin defenses in old growth ponderosa pine (Crater Lake, Oregon): four years of post-fire monitoring. Natural Areas Journal 31:14-25.

Pickett, S. T. A., and P. S. White. 1985. The ecology of natural disturbance and patch dynamics. Academic Press, San Diego, California, USA.

Powell, E., and K. Raffa. 2011. Fire injury reduces inducible defenses of lodgepole pine against mountain pine beetle. Journal of Chemical Ecology 37:1184-1192.

Powell, E. N., P. A. Townsend, and K. F. Raffa. 2012. Wildfire provides refuge from local extinction but is an unlikely driver of outbreaks by mountain pine beetle. Ecological Monographs 82:69-84.

Pyne, S. J. 1982. Fire in America: a cultural history of wildland and rural fire. Princeton University Press, Princeton, New Jersey, USA.

Raffa, K. F., B. H. Aukema, B. J. Bentz, A. L. Carroll, J. A. Hicke, M. G. Turner, and W. H. Romme. 2008. Cross-scale drivers of natural disturbances prone to anthropogenic amplification: the dynamics of bark beetle eruptions. BioScience 58:501-517.

Raffa, K. F., and A. A. Berryman. 1983. The role of host plant resistance in the colonization behavior and ecology of bark beetles (Coleoptera: Scolytidae). Ecological Monographs 53: 27-49.

Rigling, A., H. Brühlhart, O. U. Bräker, T. Forster, and F. H. Schweingruber. 2003. Effects of irrigation on diameter growth and vertical resin duct production in Pinus sylvestris L. on dry sites in the central Alps, Switzerland. Forest Ecology and Management 175:285-296.
Roberds, J. H., B. L. Strom, F. P. Hain, D. P. Gwaze, S. E. McKeand, and L. H. Lott. 2003. Estimates of genetic parameters for oleoresin and growth traits in juvenile loblolly pine. Canadian Journal of Forest Research 33:2469-2476.

Rodríguez-García, A., R. López, J. A. Martín, F. Pinillos, and L. Gil. 2014. Resin yield in Pinus pinaster is related to tree dendrometry, stand density and tapping-induced systemic changes in xylem anatomy. Forest Ecology and Management 313:47-54.

Rosner, S., and B. Hannrup. 2004. Resin canal traits relevant for constitutive resistance of Norway spruce against bark beetles: environmental and genetic variability. Forest Ecology and Management 200:77-87.

Ryan, K. C., E. E. Knapp, and J. M. Varner. 2013. Prescribed fire in North American forests and woodlands: history, current practice, and challenges. Frontiers in Ecology and the Environment 11:e15-e24.

Sala, A., G. D. Peters, L. R. McIntyre, and M. G. Harrington. 2005. Physiological responses of ponderosa pine in western Montana to thinning, prescribed fire and burning season. Tree Physiology 25:339-348.

Santoro, A. E., M. J. Lombardero, M. P. Ayres, and J. J. Ruel. 2001. Interactions between fire and bark beetles in an old growth pine forest. Forest Ecology and Management 144: 245-254.

Schmidt, K. M., J. P. Menakis, C. C. Hardy, W. J. Hann, and D. L. Bunnell. 2002. Development of coarse-scale spatial data for wildland fire and fuel management. General Technical Report RMRS-GTR-87. USDA Forest Service, Rocky Mountain Research Station, Fort Collins, Colorado, USA.

Schoennagel, T., T. T. Veblen, and W. H. Romme. 2004. The interaction of fire, fuels, and climate across Rocky Mountain forests. BioScience 54:661-676.

Six, D. L., and M. J. Wingfield. 2011. The role of phytopathogenicity in bark beetle-fungus symbioses: a challenge to the classic paradigm. Annual Review of Entomology 56:255-272.

Smith, C. C. 1970. The coevolution of pine squirrels (Tamiasciurus) and conifers. Ecological Monographs 40:349-371.

Spiller, D. A., and A. A. Agrawal. 2003. Intense disturbance enhances plant susceptibility to herbivory: natural and experimental evidence. Ecology 84:890-897.

Stahel, W. A. 2002. Statistische Datenanalyse: Eine Einführung für Naturwissenschaftler. Fourth edition. Vieweg, Braunschweig, Berlin, Germany.

Stephens, S. L., J. J. Moghaddas, C. Edminster, C. E. Fiedler, S. Haase, M. Harrington, J. E. Keeley, E. E. Knapp, J. D. McIver, and K. Metlen. 2009. Fire treatment effects on vegetation structure, fuels, and potential fire severity in western U.S. forests. Ecological Applications 19:305-320.

van Mantgem, P. J., J. C. B. Nesmith, M. Keifer, E. E. Knapp, A. Flint, and L. Flint. 2013. Climatic stress increases forest fire severity across the western United States. Ecology Letters 16:1151-1156.

Wallin, K. F., T. E. Kolb, K. R. Skov, and M. R. Wagner. 2004. Seven-year results of thinning and burning restoration treatments on old ponderosa pines at the Gus Pearson Natural Area. Restoration Ecology 12:239-247.

Young, T. P., and B. D. Okello. 1998. Relaxation of an induced defense after exclusion of herbivores: spines on Acacia drepanolobium. Oecologia 115:508-513.

\section{Supplemental Material}

\section{Ecological Archives}

Appendices A-C are available online: http://dx.doi.org/10.1890/14-0487.1.sm 